\title{
How is the United States's international HIV prevention programme evolving?
}

\author{
Christine Evain
}

\begin{abstract}
The President's Emergency Plan For AIDS Relief (PEPFAR) is a 1998 United States governmental initiative to prevent the spread of AIDS, primarily in Africa. The PEPFAR program has provided antiretroviral treatment to over 11 million HIV-infected people in Africa and it has been called the largest health initiative ever initiated by one country to address a disease, with a budget exceeding $\$ \mathbf{7 0}$ billion since its creation. While PEPFAR has been praised for having saved millions of lives, diminishing media attention to AIDS as well as potential policy changes are likely to negatively impact the progress of the organization in the future. Thus a number of questions arise: How has PEPFAR's policy been driven and assessed so far? What are the key factors which have led to PEPFAR's success? How does it measure its own efficiency? How does PEPFAR compare to other international organizations? What are its links with local organizations? How does it relate to its partners? The aim of this paper is to consider these important questions and to map out the shifting balance of HIV prevention in the next decade. This study is based on the institutional documentation, press articles as well as on a series of interviews conducted with local members of HIV/AIDS Disease Control and Prevention programmes in Africa.
\end{abstract}

Key words: President's Emergency Plan For AIDS Relief (PEPFAR), AIDS Relief, United States, Foreign aid, HIV prevention, Uganda

\section{INTRODUCTION}

The President's Emergency Plan For AIDS Relief, known as PEPFAR, is a United States governmental initiative to prevent the spread of AIDS, primarily in Africa. The initiative for this programme dates back to 1998, when presidential candidate George W. Bush, in collaboration with Condoleezza Rice, chose to focus on Africa and foster public sympathy which resulted in the creation of PEPFAR (Varmus 2013).

Today, the PEPFAR documentation and website show that the program has provided antiretroviral treatment to over 11 million HIV-infected people in Africa. HIV testing and counselling (HTC) is available in resource-limited settings in many African countries and has been beneficial to millions people. PEPFAR has been called the largest health initiative ever initiated by one country to address a disease, with a budget exceeding $\$ 70$ billion since its official creation in 2003.

While PEPFAR has been praised for having saved an estimated 11 million lives, diminishing media attention to AIDS as well as potential policy changes are likely to negatively impact the progress of the organization in the future. Furthermore, some critics contend that foreign aid is generally inefficient and are therefore in favour of an American withdrawal (Alcorn 2015).

In this context of change a number of questions arise: How has PEPFAR's policy been driven and assessed so far? What are the key factors which have led to PEPFAR's success? How does it measure its own efficiency? How does PEPFAR compare to other international organizations? What are its links with local organizations? How does it relate to its partners? What type of 
local initiatives could replace PEPFAR in the future? Are these local institutions capable of playing the same role as PEPFAR? What is PEPFAR likely to offer in the present presidential context? The aim of this paper is to consider these important questions and to map out the shifting balance of HIV prevention in the next decade.

The press largely report cries of alarm, for example the much-quoted Bill Frist, former Republican Senate leader, known for his famous urgent plea for continuing the PEPFAR program. The U.S. Global AIDS Coordinator and U.S. Special Representative for Global Health Diplomacy, Ambassador Birx, has never missed an opportunity to defend the programme publicly. This collaborative advocacy in favour of PEPFAR has not been in vain, as we will show in the present article.

Our study is based on the documentation previously quoted as well as on a series of interviews conducted with local members of HIV/AIDS Disease Control and Prevention programmes in Africa.

We will first describe the programme up to the Trump election. We will look at the results of the programme and its assessment methods. We will then analyse the ambivalence of both President Trump and Trump's supporter in relation to the programme. Finally, we will explore some of the uncertainties of the future.

\section{DESCRIPTION OF PEPFAR, PEPFAR RESULTS AND ASSESSMENT METHODS}

When the broad public became aware of the AIDS epidemic in the 1980s, the world was in shock. The disease was revealed to be gruesome and deadly, and there was no medical cure in sight. Famous actors, musicians, and other celebrities in the world helped to raise the public's awareness about the threat of the disease. Many Internet pages serve as a testimony to their activism: dozens of famous people who are living with AIDS or who died of AIDS, are listed online, offering hyperlinks to well-documented records and reports which include pictures, biographical information and quotes (Provost 2012, Firger 2016, Crossan 2017, Davis 2017).

It was thanks to this activism, which signed up the support of the many associations and groups coming to the defence of stigmatized communities, that the US government was spurred to take action. Campaigners stood up for the rights of the patients and for the rights of the community that were being infected. In that same decade, the scientific research community, including the famous Institut Pasteur team, gradually made headway into finding the first leads for treating the disease (Mugyenyi 2012), soon followed by prominent scientists around the world (Rushton, 2015). Indeed, "activism led to an awareness", says Ambassador Mark Dybul, executive Director of "The Global Funds to Fight Aids", "And then there was scientific advance" (Tehrani, Noble 2016).

While it was Clinton who started the Clinton Foundation's Health Access Initiative (CHAI) in 2002, thus demonstrating his strong interests in improving health in the developing world, he was not the president who created PEPFAR. One may ask: why wasn't the programme launched under his presidency? The answer to that question is simple: it was only in the later years of the Clinton administration, that effective therapy against HIV came into common practice. Back then, even in advanced economies, the costs of such therapy favoured limiting efforts in poor countries to less expensive preventive measures. Furthermore, the political landscape of the time, with President Clinton in the midst of impeachment proceedings, did not favour the passage of ambitious programs that he had initiated. As a result, although Clinton did strongly support research on HIV/AIDS and even developed small exploratory programs in 
three African countries, the PEPFAR plan did not come into being before 2003, under Bush's presidency.

PEPFAR was created in a moment of crisis: it had been known, since the late 1990s, that H.I.V./AIDS was the No. 4 killer worldwide, and No. 1 in Africa, but it was only in the spring of 2002, that Mr. Bush sent Mr. Thompson and the government's top AIDS expert, Dr. Anthony S. Fauci, to Africa "to try to scope out anything we could do in a humanitarian way," Dr. Fauci said. (Stolberg 2008)

The experts came back and proposed $\$ 500$ million to prevent mother-to-child transmission of the disease. The president approved the budget, Dr. Fauci said, but told them to think bigger. "He wanted to do something game-changing," Mr. Bolten said. "Something that, instead of at the margins assuaging everybody's conscience, might actually change the trajectory of this disease which, from the reports we were getting, was headed to destroy a whole continent." (Stolberg 2008)

In effect, PEPFAR's objective was to commit approximately $\$ 15$ billion from 2004 to 2008 to assist with the reduction of the HIV pandemic worldwide. The majority of the PEPFAR policy and funding focused on 12 countries in sub-Saharan Africa: Botswana, Cote d'Ivoire, Ethiopia, Kenya, Mozambique, Namibia, Nigeria, Rwanda, South Africa, Tanzania, Uganda, and Zambia. (Chin and al. 2015)

The press expressed surprise at a Republican president making such a decision ${ }^{1}$ : "The story of how a conservative Republican president became a crusader against global AIDS is an unlikely one." (Stolberg 2008). However, it is important to move beyond bipartisan commentaries and to simply stress that, ever since its creation in 2003, PEPFAR has received strong support from American presidents (McGreal 2008) through different administrations, including, as stated on the PEPFAR website "two reauthorizations with significant majorities." It is thanks to this bipartisan support that the United States became, as stated on the PEPFAR website "the world's leader in responding to the global HIV/AIDS crisis."

According to Bill Frist ${ }^{2}$, the programme aims "to bring reliable, proven measures like antiretroviral drugs, counselling and prevention services to underserved communities around the world." (Varmus 2013) Year after year, the PEPFAR reports have demonstrated the efficiency of the programme and the need for continued efforts.

\section{PEPFAR RESULTS}

The impact of the programme is presented using the World Health Organization (WHO) health system six building blocks ${ }^{3}$. The reports show that the PEPFAR program has indeed improved the delivery of prevention and care services for people living with HIV/AIDS (PLWHA). The most important measure of PEPFAR's success is the availability of free antiretroviral therapy (ART) in focus countries for people living with HIV/AIDS. ART figures only become meaningful when related to an understanding of the spreading of the disease in focus countries. PEPFAR's role is to gain insight into such questions.

\footnotetext{
${ }^{1}$ Much of the credit can be given to Condoleezza Rice whose help and guidance were invaluable.

${ }^{2}$ Bill Frist is a former Republican Senate majority leader from Tennessee, is the chairman of the executive board of the health care investment firm Cressey \& Company, a senior fellow at the Bipartisan Policy Center and a cochairman of the center's work on health innovation.

3 These include service delivery, health workforce, health information, medical products, vaccines and technologies, financing and governance.
} 
Analyzing PEPFAR's results also implies assessing the programme's impact on increasing political awareness of public health by governments and civil society. Does the programme actually raise the priority given to public health issues and does it lead government to scale up its response to HIV/AIDS?

The scaled-up program has direct benefits on the health workforce by preserving HIV-infected health personnel's lives so that they can live longer - as the PEPFAR report figures indicate and that implies they can return to their jobs, which inevitably enhances the country's workforce. Moreover, the training and retraining in PEPFAR HIV/AIDS programmes have improved both the morale and the skills of the health workforce. Considerable resources have been brought into focus countries on a scaled-up HIV/AIDS treatment by PEPFAR.

The results of the programme are easily accessible, in an extensive report, on the PEPFAR website. They are also presented at international conferences on AIDS mainly by Ambassador Deborah Birx, who is the U.S. Global AIDS Coordinator and U.S. Special Representative for Global Health Diplomacy.

To summarize PEPFAR'S main accomplishments, in a few bullet points:

- When PEPFAR began, only 50,000 people in sub-Saharan Africa were receiving antiretroviral treatment. That number is now 11.5 million, which represents a 50 percent increase since just 2014. As a result, one of the most dramatic aspects of PEPFAR's success is the effect on life expectancy: "After the arrival of the HIV/AIDS epidemic in the 1980s and prior to the initiation of PEPFAR in the early 2000s, life expectancies had been falling precipitously in African countries with a high prevalence of HIV infection. But the number of deaths in such countries fell steeply after the start of PEPFAR. Effects like these explain why PEPFAR has such high visibility in many African countries and has inspired so much gratitude toward the United States. Moreover, unlike previous programs that may have had a paternalistic taint, PEPFAR also achieved solid bilateral partnerships, thereby building and strengthening U.S. ties in that region." (Varmus 2013)

- Nearly 2 million babies have been born free of HIV who otherwise would have been infected. (PEPFAR website)

- Among the secondary victims of AIDS are the orphans of those who died in the epidemic. PEPFAR provides care and support for 6.2 million orphans. (PEPFAR website)

- More than 74.3 million people, including more than 11.5 million pregnant women, received HIV testing and counselling through PEPFAR. (PEPFAR website)

- PEPFAR supports training for nearly 220,000 new health care workers. In addition to responding to AIDS-related issues, this training has enhanced health systems' responsiveness to outbreaks of Ebola, Cholera, and other diseases. (PEPFAR website)

According to the PEPFAR report, entitled, "Strategy for Accelerating HIV/AIDS Epidemic Control (2017-2020)", recent data from PEPFAR's Population-based HIV Impact Assessments (PHIAs), show that "five high-burdened African countries are approaching control of their HIV/AIDS epidemics, demonstrating the remarkable impact of the U.S. government's efforts together with partner countries. With support from the U.S. government, seven additional high-burdened countries will complete PHIAs on a rolling basis through 2017-2019, providing the latest data to chart and validate their progress toward reaching epidemic control by 2020." (PEPFAR report 2017)

These results have been highlighted by PEPFAR (mainly through dozens of reports presented to Congress and posted on their website) and echoed in the American press (Harris 2017, Lee 
2017, Leonhardt 2017, Levey 2017, Russell 2017, Saldinger 2017, Shelbourne 2017, etc.) as well as the international press which is concerned about potential budget cuts (Kim and Whang 2017, Mbanje 2017a and b, Seib 2017, etc. ${ }^{4}$ ). Both Birx and the press underline that the programme has been able to expand, without a significant change in its budget, because it leverages the latest scientific innovations and reductions in drug prices: "PEPFAR, with a \$6.8 billion annual budget covering 31 countries, has played a key role in controlling HIV since 2003. But with stagnant funding, more efficient use of resources is required, Birx said. 'Funding has plateaued and the real challenge is how do we apply the tools that have been given to us through the scientific method and how do we do that in a budget-neutral environment.' It's important, she suggested, to focus on the 'right things, right places, right now.'" (Kristiansen 2016)

Science \& Diplomacy point out that the program has been "enlarged (for instance, to include some research on implementation of medical assistance), the roster of PEPFAR countries has grown (to include eighty countries, forty-two of which are major beneficiaries, compared with the original fifteen), and spending plans have not been exceeded." (Varmus 2013)

It is too complex, in this article, to describe the ways in which PEPFAR's missions have been carried out in collaboration with US and local agencies, academic institutions, and contractors. Suffice to say that the spending patterns can be readily summarized as follows: "about 55 percent of the funds have been used for treatment (delivery of antiretroviral medications and the detection and monitoring of HIV infection), about 35 percent for prevention (e.g., provision of information and condoms), and about 10 percent for other kinds of care (such as antibiotics and orphanage support)." (Varmus 2013)

The very structure of PEPFAR's organization aims at maximum efficiency and I will focus on giving three of the reasons which are crucial to this efficiency:

- PEPFAR operates within the American Embassy framework, which is the best way of ensuring that the programme doesn't fall prey to practices of corruption which are the burden of many African countries.

- PEPFAR organizational structure includes four key branches: prevention, treatment, care and statistics. This organizational structure is repeated in all PEPFAR countries, and professional methods and tools are shared between the different PEPFAR location to maximize efficiency and impact.

- The programme is well up to speed on scientific innovations and seeks reductions in drug prices. The latest innovation is the introduction of a vaccine which is now being tested (Doshi and al. 2017, Nyaoke and al 2017, O'connor 2017, Opeyemi 2017 Senthilingam 2017a and b).

Finally, let us stress the importance of the high standards of PEPFAR employees as well as the efforts put in to create a harmonious collaboration between American and local employees. Both share the same goals, dedication and public health service values - beyond any cultural and professional differences.

\section{CRITICISM OF PEPFAR}

When examining academic papers which analyse PEPFAR's results, one comes across harsh, and unfair criticism of the programme (Chin and al. 2015). While it is generally acknowledged

4 This concern is not new. For a number of years, international aid groups have expressed fears that the international economic downturn threatens AIDS funding (Bryson 2009, Barton-Knott 2016, etc.). 
that PEPFAR has underlined the negative role of stigma in fueling the HIV epidemic, several researchers claim that the programme has, according to Hagopian et al. "so far, missed opportunities to explicitly address the role of the criminalization of homosexuality in feeding stigmatizing attitudes" (Hagopian et al. 2017). Their analysis concludes, however, that "mechanisms like PEPFAR Partnership Framework agreements could be ideal vehicles to call for removal of anti-homosexuality legislation". Similarly, Kim and Whang focus on the effects of the programme on the economies and domestic politics of focus countries and find that their "results show that PEPFAR did improve economic conditions in focus countries but had a limited impact on political conditions, that is, on democracy and human rights." (Kim, Whang 2017).

All beneficiary country reports and testimonies run contrary to such findings. While, in the past, PEPFAR has indeed been criticized for directing a portion of its budget to abstinence education (Rosenthal 2008) ${ }^{5}$, the programme is now clearly stating the limits of the abstinence-only approach -from Le Monde back in 2005, to today, all over the world (La Depeche 2017, Rabesandratana 2016, Osi 2017, Adekemi 2017, etc.) ${ }^{6}$.

As for PEPFAR's impact on the political situation in focus countries, the question is complex. PEPFAR's programme is a non-political one, focusing on public health issues. While these issues cannot be dissociated from social issues, Hagopian et al. are merely stating the obvious when they write: "Laws that penalize same-sex intercourse contribute to a cycle of stigma, homonegativity and discrimination. In many African nations, laws criminalizing homosexuality may be fueling the epidemic, as they dissuade key populations from seeking treatment and health care providers from offering it." (Hagopian et al. 2017). PEPFAR clearly does not miss "opportunities to explicitly address the role of the criminalization of homosexuality in feeding stigmatizing attitudes" (Hagopian et al.) and evidence of such public address is given in the many reports, conferences, and interview videos of the U.S. Global AIDS Coordinator Ambassador Deborah Birx.

The impact of PEPFAR's work is visible: "PEPFAR has helped stabilize much of Africa" claims Frist (2017). In a 2015 extensive report for the Bipartisan Policy Center, entitled "The Case for Strategy Health Diplomacy: A Study of PEPFAR", Frist and Senate colleague Tom Daschle report the findings of researchers who compared countries that received PEPFAR assistance and, as a control, similar countries that did not. The results were dramatic: "From 2004 to 2013, political instability and violence fell by 40 percent in countries that received PEPFAR

\footnotetext{
${ }^{5}$ A study was carried out to look at trends in behaviour prior to the introduction of PEPFAR funding of the abstinence-related measures: no significant change was found in PEPFAR countries relative to non-PEPFAR countries over time for any of the abstinence measures: "Nearly US $\$ 1.3$ billion spent on US-funded programmes to promote abstinence and faithfulness in sub-Saharan Africa had no significant impact on sexual behaviour in 14 countries in sub-Saharan Africa, an analysis of sexual behaviour data has shown. [...] The researchers looked at trends in sexual behaviour derived from national Demographic and Health Surveys in 14 PEPFAR focus countries before and after the beginning of PEPFAR funding in 2004, and compared these to a counterfactual: trends in eight other African countries - largely in West Africa - where PEPFAR funding was not determining the content of prevention campaigns." (Alcorn, 2015) As for antiabortion policies, the Trump administration claims they need to be expanded in order to have an impact on the global HIV/AIDS epidemic although previous research runs contrary to such claims (McKay 2017). Meanwhile, lifetime risk of HIV Diagnosis continues to rise in the United States: "If current HIV diagnoses rates persist, about 1 in 2 black men who have sex with men (MSM) and 1 in 4 Latino MSM in the United States will be diagnosed with HIV during their lifetime, according to a new analysis by researchers at the Centers for Disease Control and Prevention (CDC)". (Villarosa 2017)

${ }^{6}$ It is clearly still problematic to steer away from the abstinence discourse in several African countries for religious reason (Tocco 2017). The anti-gay culture only creates further difficulties (Sieff 2016).
} 
assistance versus just 3 percent in similar countries that did not. Measurements of the strength of the rule of law increased 31 percent versus just 7 percent.

And it has paid dividends for America's image abroad. In 2007, just as PEPFAR was taking hold, both PEPFAR and non-PEPFAR countries in Africa gave the United States approval ratings of about 40 percent, but by 2011 the rating in PEPFAR countries had risen to about 80 percent, while in non-PEPFAR nations it had risen only to around 50 percent." (Frist 2017)

Furthermore, Deborah Birx stresses that the success of the programme depends largely on the success of the collaboration with local authorities. This implies a collaboration and a quality of communication which branch directors at PEPFAR greatly value and promote.

\section{STRATEGIC PLANNING AND ASSESSMENT METHODS}

The assessment methods of the programme are not only essential to evaluate the success of the programme but they are also essential to the very success of the programme: the data informs strategic planning and operational development and therefore the data is where everything begins.

Assessment methods were put into place and built into the legislation, since the inception of the programme: "Bush asked for accountability in foreign assistance programs, and regular assessments by the Institute of Medicine (IOM)" (Varmus 2013). PEPFAR's annual reports are organized thematically or by country ${ }^{7}$. They not only map out the achievements, but also highlight the milestones on the road ahead.

Building on their tremendous progress, PEPFAR is now "poised to accelerate progress toward reaching epidemic control, something that was unimaginable just a decade ago. (PEPFAR website)

The PEPFAR Strategy for Accelerating HIV/AIDS Epidemic Control (2017-2020) ("Epidemic Control Strategy") focuses specifically on 13 priority, high-burdened countries. In those countries, the number of new infections each year is still alarmingly high.

\footnotetext{
7 These reports include: PEPFAR Country/Regional Operational Plans (going back to 2007), for over 30 countries; "Annual Reports to Congress", the PEPFAR Dashboards, messages from PEPFAR's Leadership and other reports such as:

"PEPFAR 3.0 - Controlling the Epidemic: Delivering on the Promise of an AIDS-free Generation" "Accelerating Children's HIV/AIDS Treatment Report”,

"Building on Firm Foundations:The 2015 Consultation on Strengthening Partnerships",

"Between Faith-based Organizations and PEPFAR to Build Capacity for Sustained Responses to HIV/AIDS",

"The PEPFAR Consultation on the Role of Faith-based Organizations in Sustaining Community and Country", "Leadership in the Response to HIV/AIDS(2012)". (PEPFAR website).
} 


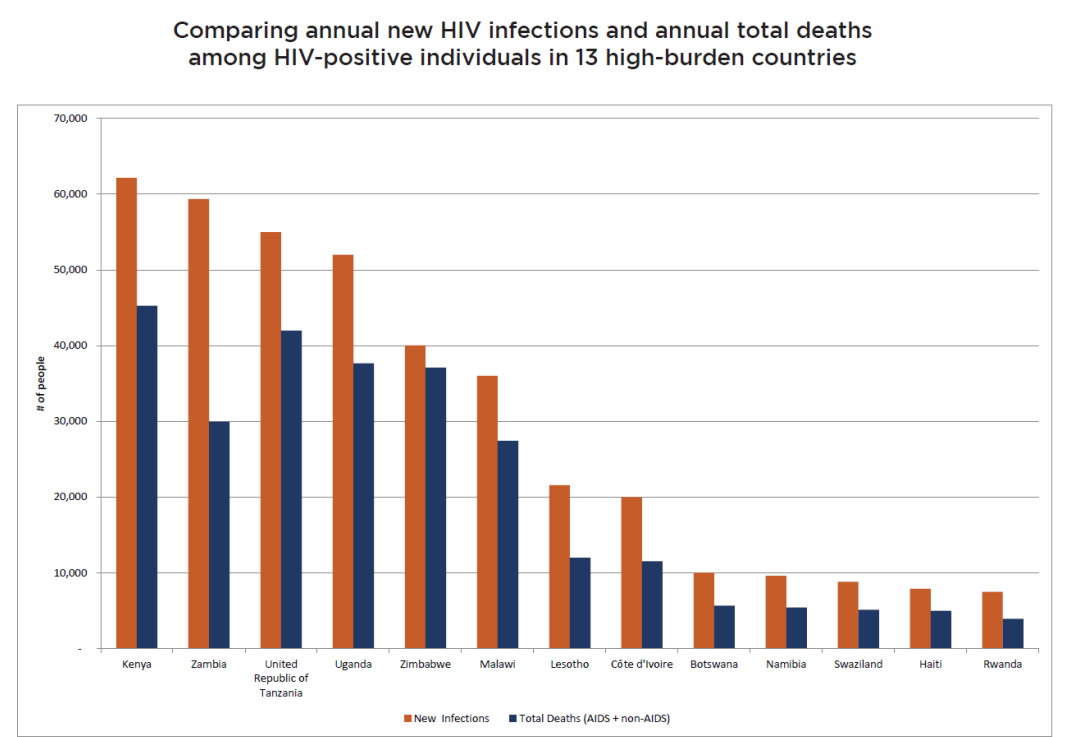

Source: PEPFAR Strategy for Accelerating HIV/AIDS Epidemic Control (2017-2020)

Reducing the number of new infections will be accomplished in partnership with and through attainment of the UNAIDS 90-90-90 framework. This framework is built on the well-known fact that every epidemic has a tipping point. For H.I.V. there are 3 targets that must be met for that tipping point to be reached: that 90 percent of people with the virus are aware they have the virus, that 90 percent of that group are receiving treatment and that 90 percent of those taking antiretroviral medicine control the virus to the point where it cannot be transmitted. Such a strategy is the goal of UNAIDS, which hopes to achieve the 90-90-90 tipping point everywhere in Africa by 2020, which would be the death knell of the HIV/AIDS epidemic.

While this strategy is working, stubborn challenges remain. As the above graph shows, people continue to be infected, and the broad public has perhaps little knowledge of the subject because it is poorly reported in the press. A few articles have recently come to raise awareness, and the public's awareness about the subject: "Around one million still die from the virus every year and while 53\% of PLWHA now have access to treatment, a significant number still do not." (Purvis 2017). These claims are supported by the figures to be found in PEPFAR reports.

At present, the global HIV community of researchers, policymakers and healthcare providers is working towards UNAids' 90-90-90 targets. PEPFAR has won the support of partner countries who are now helping to adopt and implement the World Health Organization (WHO) Guidelines for "Test and START", as well as more efficient service delivery models.

According to Varmus, the WHO guidelines will "prevent more new HIV infections, save more lives, and accelerate progress toward the UNAIDS “90-90-90" goals.

Most high-burdened countries have already eliminated mother-to-child transmission with a coverage of HIV-positive pregnant and breastfeeding women on ART of $98 \%$, and an early mother-to-child HIV transmission rate lower than 5\%. In Uganda, for example, the success of the prevention of mother-to-child transmission (PMTCT) program resulted in achieving the first and second elements of the 90-90-90 framework in the children-under-15 age group: $91 \%$ of children were diagnosed and $82 \%$ were put on treatment. In that same country, the first 90 objective has also been achieved in women, with $90 \%$ being diagnosed; of these, $79 \%$ are on treatment, making the achievement of the second 90, among women, likely by the end of 2017 
One of the success factors of PEPFAR is that the programme capitalizes on the latest scientific breakthroughs and reductions in drug prices. The evolution of the medicine has been significant in the last 15 years. The treatment is now not only cheaper and more effective, but also easier to administer: it has moved from being 3 pills, 3 times a day to one pill a day. However, there are complications with the HIV virus as it continuously replicates: this means the treatment is not as effective when people come to care at a very late stage in their illness. Early detection processes include routine screening. In some heavy-burdened countries, the law has changed from opt in to opt out screening, and the objective is now to run several million tests a year (for example, 8 million tests a year in Uganda).

Regular screening is quick, unlike DNA testing which involves sending a sample to a lab and getting it back a month later. In the case of babies, when their mothers are HIV positive, they will test HIV positive as well, because they inherit their mothers' antibodies, but that does not necessarily mean they are infected. A subsequent test needs to be carried out to determine whether or not they are HIV positive. When they are 18 months old, the babies no longer carry their mothers' antibodies. Testing can be easily organized with women because almost every woman receives care during a pregnancy and most women have early pregnancies. With men, the testing coverage rate is much lower. High-burdened countries have started introducing systematic testing in prison because prisons are a good opportunity to test men. But even when such measures are introduced, it takes time before all institutions are operationally on board.

The PEPFAR prevention program includes an ambitious circumcision objective as circumcision reduces HIV contamination by $60 \%$. In most countries, there are as many men circumcised as people in treatment.

Deborah Birx, previously mentioned. Deborah Birx is the person who determines how the Country Operational Plan (COP) needs to be carried out. She also sets the periodicity of the surveys to be conducted. A yearly survey objective is set in most PEPFAR countries - which is quite an ambitious objective given the extent of the survey. Typically, the COP involve more than 1000 facilities. For each of the facilities, specific targets are set on large spreadsheets handled by a team of statisticians.

The collaboration between local institutions and the Americans is the result of hard work in order to overcome the difficulties of having different approaches (Chidza 2017, Downie 2017). The American teams have built experience because 15 of these surveys are being done simultaneously, on a regular basis, across Africa. The local teams are good at determining the clusters - they usual have census experience recently and they know how to go about it. Challenging surveys, which typically include several million people, have been carried out in all high-burdened countries (see reports on PEPFAR website). A new sampling method has recently been introduced by CDC in order to gauge the population size and it has been tested within the sex worker community. This method is similar to the wildlife tagging methodology whereby surveyors catch a sample, tag the animals, and throw them back into their wild habitat. On the next round of sampling surveyors can estimate the population size which relates to the number of tagged animals which were caught on the second round. This method, when transferred to humans, does not involve tagging them but giving them a few objects that they will then pass around to their friends (these objects are relatively cheap, but their perceived value is high enough for the sex workers to pass them around). Although this method works quite well, it is always difficult to determine the population size of sex workers because there are different classes of sex workers which do not mix: the higher classes frown upon the lower ones. Regardless of the sample characteristics, it's important to do the tests 
even when people say they are not infected. The issue is that people may not know their status and, furthermore, some people who know they are positive may self-report as negative due to stigma. Because of this inaccurate self-reporting, health information systems (EHIS), PEPFAR supports the introduction of electronic EHIS. These systems assist with patient and program management, disease surveillance, and strategic use of information for overall quality improvement. Thus Electronic EHIS are more responsive and more efficient than previous nonelectronic information systems and they are central to strong health systems (Moucheraud and al. 2017)

\section{FOREIGN AID PROGRAMS AND THE TRUMP ADMINISTRATION}

While Trump's electoral discourse was largely in favour of PEPFAR, the post-election discourse seeks to exploit scepticism about foreign aid. It was soon after the election that Trump had a change of heart in relation to PEPFAR. The press were quick to notice and to report back on it: a few days after Trump was sworn into office, The New York Times wrote that "the Trump transition team was asking questions about the value of humanitarian aid in general and PEPFAR in particular. For example, transition officials asked, 'Is PEPFAR worth the massive investment when there are so many security concerns in Africa?'” (Frist 2017). Ms. Muyangwa said the queries signaled "a dramatic turn in how the United States will engage with the continent." (Cooper 2017).

Scepticism about the value and effectiveness of foreign aid programmes is not new and it is often fuelled by misperceptions about the figures and the percentage of Federal expenditure that foreign aid actually accounts for. Some Americans, when asked, have imagined that foreign aid accounts for $25 \%$ of Federal expenditure, when in fact it only accounts for $1 \%$. (Cooper 2017)

A case in point is how much the American government has spent on hunting for Mr. Kony, who, according to both Ugandans and national authorities has now completely disappeared and is no longer a threat to the country. (Okiror 2017)

Another misconception is the amount of American aid spent in Africa, in relation to other countries: In 2015, America spent far more on other critical allies: "[The budget spent on] Afghanistan ( $\$ 5.5$ billion), Israel ( $\$ 3.1$ billion), Iraq ( $\$ 1.8$ billion) and Egypt ( $\$ 1.4$ billion) (.. ) far exceeded the approximate $\$ 8$ billion for all of sub-Saharan Africa. (Cooper 2017)

There is no doubt that there is genuine concern among many Americans, that foreign aid budgets are too high, and that money is often squandered, and that is precisely what Trump is capitalizing on when he announces budget cuts.

Another criticism, which is sometimes juxtaposed against the exaggerated drain on the national budget of foreign aid programmes, is that these programmes are merely sticking plasters and that they don't actually address the systemic and root causes of many of the problems in these countries, which relate to a lack of resources and infrastructure, poor and corrupt government and social stigma against the illness that inhibit progress. In other words, foreign aid is said to be wasted, ill-spent: it fails to find its way to those who need it or for whom it was intended, but rather is siphoned-off for corrupt purposes and in the worst cases, falls into the hands of warlords and corrupt regimes that use the money for personal advantage and/or to buy armaments, rather than food and medication.

In many African countries, corruption is both endemic and routine. It is a well-known fact that some foreign aid agencies are party to that day-to-day corruption, in order to get things done. 
For example, when goods are shipped to African countries in need, if shipment is not handled by an Embassy, they are likely to fall into the hands of corrupt customs officers, and bribes need to be paid for the goods to be released to the NGO they are intended for.

Finally, the American people's ambivalence is also motivated by conflicting questions: on the one hand, Americans want to defend their economic interests in Africa, on the other hand, they are worried about spending too much public money on humanitarian projects in Africa.

Cooper echoes such economic concerns: "How does U.S. business compete with other nations in Africa? Are we losing out to the Chinese?" (Cooper 2017) However, concerns about the programme being a public expenditure that the American economy cannot afford leads to queries about humanitarian assistance money. "With so much corruption in Africa, how much of our funding is stolen? Why should we spend these funds on Africa when we are suffering here in the U.S.?" (Cooper 2017)

The response to that argument is that the concern of America and Western countries has never been purely altruistic in relation to Africa. The initiative and desire to slow and stop the spread of HIV/AIDS was, and still is partly, driven by a desire to stop the spread of the disease in other parts of the world and not least, in the United States. It should be noted that Trump hailed and commended the work of PEPFAR during his presidential campaign, but is now taking a different stance in office. Journalists express their frustration with Trump's approach. Shingirai Huni in the Herald Zimbabwe entreats the world to stop "this village bully" (in other words, Trump) who uses health interventions to "guarantee America of a strong market for its finished goods and services" (Huni 2017). Nicholas Kristof exclaims: "it's maddening to see world leaders posturing in the spotlight and patting themselves on the back while doing so little to tackle humanitarian crises that they themselves have helped create" (Kristof 2017). Kristof's point is that poverty has fuelled AIDS in Africa, and most Western Nations - through slave trade or colonization - have fuelled that very poverty which greatly contributed to the spread of the virus. Therefore, both America and Western countries should consider AIDS not just as an African problem but as a world problem, not only in its causes, but also in its consequences.

\section{ADVOCACY FOR THE PROGRAM AND THE TRUMP ADMINISTRATION'S AMBIVALENT ATTITUDE TO THE PROGRAMME}

In May 2017, journalists covering the debate issued out a warning cry: "If Trump gets his way, development aid would be cut by nearly one-third. This is a severe blow, but not surprising, given how slow the Trump team was to engage with USAID, the main government aid body" (Anderson 2017). During the presidential transition, Trump's repeated election statements were that he would "stop sending foreign aid to countries that hate us" and instead invest at home in schools and infrastructure. (Anderson 2017) More virulent comments included: "Trump "simply Does Not Care" about HIV/AIDS" (Wang 2017) or Trump Budget Would Set Back Global AIDS Fight Just When We're on Track to Win It (Warren 2017).

Perhaps PEPFAR was victim of its own success, as the depth of investment and organization in sub-Saharan Africa - where rates of HIV infection were the highest in the world and were increasing at an exponentially faster rate than anywhere else in the world - had enabled PEPFAR to come pretty close to halting the spread of the disease and thus many imagined, the threat was now over. This perception of a 'job done' and the grim austerity measures of a postfinancial crisis world, did prompt Trump's supporters to argue that it is right and legitimate to rein in expenditure on such costly foreign aid programmes. 
However, as the most recent chapter in this saga has shown, it is not the President that has the final say, but Congress which decides on the budget. Strong advocacy in favour of maintaining PEPFAR's budget paved the way for the Congressional decision in Autumn 2017: "Many politicians and global actors have opposed the proposed cuts. More than 100 retired admirals and generals penned an open letter arguing that aid and diplomacy are essential to national security." (Anderson 2017). These advocates demonstrated that the budget US President Donald Trump had submitted to Congress would throw PEPFAR's progress into reverse. As Rosenberg underlines, Trump "proposed a cut of $\$ 2.5$ billion to America's global health budget - \$1bn less for Pepfar and \$ 225 million less for the Global Fund. Millions of people would have lost their treatment, and the epidemic would have once again picked up steam". (Rosenberg 2017a) As a result, both the House and Senate appropriations committees ignored Trump's budget cuts, and approved funding at the same level as the previous year. It must be noted, however, that "Senator Patrick Leahy, a Democrat from Vermont, proposed adding $\$ 500 \mathrm{~m}$, but it was voted out, along party lines." (Rosenberg 2017a)

However, while Congress votes on budgets, the Trump administration still shapes how aid is delivered and therefore advocates of the programme are still following the developments of this affair closely. Journalists reporting back have warned "It is at least possible that the Trump administration could experiment with new ideas like cash transfers - the direct payment of money to a beneficiary - an approach that is supposed to 'bypass corrupt officials and crafty middlemen' and get money straight to individuals. Recent studies find that cash-based programmes perform better than other kinds of aid." (Anderson 2017) However cash transfers are heavily criticized within the aid community, and are said to generate new forms of inefficiency and waste. Meanwhile proponents of Trump's measures claim that "the skeptics are just worried that a shift to cash would leave aid experts without work to do." (Anderson 2017)

Although the issue of PEPFAR's funding needs to be followed closely, the programme's advocates have made their point which has been heard by Congress. If funding had been withdrawn the projections show that there would have been an immediate and exponential spread of the disease, which would not only be catastrophic in terms of infection and mortality, but would then imply an even greater investment in the future to bring the disease back under control again. In its new report, Secretary of State Rex W. Tillerson speaks on behalf of the Trump administration to say announce the new PEPFAR Strategy for the next three years (2017-2020):

"This strategy includes investing in more than 50 countries with three concrete goals in mind. First, to maintain life-saving treatment for those we currently support, while making essential services like testing linked to treatment more accessible. Second, to provide even more services for orphans and vulnerable children - those who are immediately and permanently affected when a parent or caretaker is lost to this disease. Finally, to accelerate progress toward controlling the pandemic in a subset of 13 countries, which represent the most vulnerable communities to HIV/AIDS and have the potential to achieve control by 2020." (PEPFAR website)

It is perhaps a little ironic to hear the Trump Administration say that it remains "deeply committed to the global HIV/AIDS response and to demonstrating clear outcomes and impact for every U.S. dollar spent", after having proposed budget cuts, and lobbying communities therefore remain cautious. However, the main point is that the Trump administration is now united in delivering an official statement: "We want to look back together and recognize that it was here, at this point in time, that our accelerated focus led to a world free of HIV/AIDS. We are proud to partner with many others in this endeavor. Our support - and our commitment - 
are unwavering as we work together to control and ultimately end this pandemic, once and for all." (Lavers 2017).

\section{CONCLUSION}

As the data in this article shows, we have not reached the end of the AIDS epidemic in both Africa and, potentially, throughout the world. PEPFAR's goal has always been to shift the financial responsibilities from the U.S. to the host countries in need, and close collaboration with host countries' institutions were put into place. However, their financial autonomy to fight the disease has, in practice, been hard to achieve. It has been equally difficult to find other sources of funding internationally, but progress has been made.

The moral and political case for PEPFAR has always been strong, ever since the creation of the programme by President Bush. Both Bush and Obama have managed to rally bipartisan support for the program's funding: in spite of the American public's sometimes ambivalent support of international aid, the press has repeatedly pleaded in favour of the program, and helped raise awareness in favour of the continuation of PEPFAR. Shortly after his election, President Trump pointed both to an expanding list of beneficiaries and to the present US budgetary crises, in order to justify significant budget cuts. Thus, concern about PEPFAR's future - its dimensions, governance, funding, and activities - has been broadly expressed in the American press before and after Trump's election.

In the fall of 2017, the projections of an impending epidemic in Africa if funding was withdrawn was balanced by some optimism since Trump's budget cuts were eventually refused by his own administration. However, it is still a fact that the man in The White House does not see the battle against AIDS in Africa as a priority.

While the country data transmitted to Ambassador Birx proves that a fast-track strategy to eradicate the disease is feasible within five years, PEPFAR must continue to work within a budget that, through efficient targeting, provides steady, but sure and constant progress towards that goal. Recent research identifies populations at risk (Jordan, Edwards 2016, Onovo and al. 2017) and provides high-resolution maps of estimates of HIV prevalence in SubSaharan Africa which help to strategically target "geographic areas and populations where resources can achieve the greatest impact" (Cuadros et al. 2017). Ambassador Birx herself has proven to be extremely determined to not only ferociously defend the PEPFAR budget, but also to use data and technology and innovation to wring every last bit of value and salvation from the resources she is given. She is also seeking to extend international partnerships to complete the funding of the programme. We can trust that the American press, who have followed Trump's budget cut announcements since his election, will not allow the issue of AIDS prevention to drop off the radar and will continue to support the funding of PEPFAR. Furthermore, having closely examined the PEPFAR reports and country data, we can most certainly trust that Birx's team and partners will not take their foot off the gas pedal, until the epidemic is under control. As for us Europeans, if we believe in the importance of PEPFAR, now is the time to think about how our institutions can support the programme, not only vocally, but financially as well.

\section{BIBLIOGRAPHY}

Adekemi, Sekoni, Uthman Oluwaseun, and Somefun Esther. 2017. 'P4.99 Hiv Status Does It Make a Difference? Sexual Behaviourof Hiv Positive Men Attending a Comprehensive Treatment Centre in Lagos, Nigeria'. Sex Transm Infect 93 (Suppl 2):A227-28. https://doi.org/10.1136/sextrans-2017-053264.594.

Alcorn, Keith. 2015. 'US PEPFAR Abstinence and Faithfulness Funding Had No Impact on Sexual Behaviour in Africa'. 26 February 2015. http://www.aidsmap.com/page/2949285/. 
Anderson, Jessica. 2017. 'Trump Wants to Divert Aid Away from Women and the Environment'. Washington Post, 12 May 2017. https://www.washingtonpost.com/news/monkey-cage/wp/2017/05/12/trump-wants-to-divertaid-away-from-women-and-the-environment/.

Barton-Knott, Sophie. 2016. 'L'ONUSIDA et Le PEPFAR Annoncent Une Baisse Spectaculaire Des Nouvelles Infections À VIH Chez Les Enfants Dans Les 21 Pays Les plus Touchés Par Le VIH En Afrique | ONUSIDA'. 2016. http://www.unaids.org/fr/resources/presscentre/pressreleaseandstatementarchive/2016/june/GlobalPlan201 6.

Bryson, Donna. 2009. 'US AIDS Program Undaunted by Recession, Head Says'. Newsday. 18 November 2009.

Chidza, Richard. 2017. 'US Promises More Funds for HIV, Aids'. NewsDay Zimbabwe (blog). 8 June 2017. https://www.newsday.co.zw/2017/06/08/us-promises-funds-hiv-aids/.

Chin, Roger J., Domrongphol Sangmanee, and Lisa Piergallini. 2015. 'PEPFAR Funding and Reduction in HIV Infection Rates in 12 Focus Sub-Saharan African Countries: A Quantitative Analysis'. International Journal of MCH and AIDS 3 (2):150-58.

Cooper, Helene. 2017. 'Trump Team's Queries About Africa Point to Skepticism About Aid'. The New York Times, 13 January 2017, sec. Africa. https://www.nytimes.com/2017/01/13/world/africa/africa-donald-trump.html.

Crossan, Andrea. 2017. 'Remembering AIDS Activist Prudence Mabele'. Public Radio International. Minneapolis. https://www.pri.org/stories/2017-07-14/remembering-aids-activist-prudence-mabele.

Cuadros, Diego F., Jingjing Li, Adam J. Branscum, Adam Akullian, Peng Jia, Elizabeth N. Mziray, and Frank Tanser. 2017. 'Mapping the Spatial Variability of HIV Infection in Sub-Saharan Africa: Effective Information for Localized HIV Prevention and Control'. Scientific Reports 7 (August). https://doi.org/10.1038/s41598-017-09464-y.

Davis, Sara L. M. 2017. 'The Uncounted: Politics of Data and Visibility in Global Health'. The International Journal of Human Rights 21 (8):1144-63. https://doi.org/10.1080/13642987.2017.1348707.

Doshi, Monika, Lisa Avery, Ronnie P. Kaddu, Mary Gichuhi, Gloria Gakii, Elsabé du Plessis, Sumit Dutta, Shamshad Khan, Joshua Kimani, and Robert Lorway. 2017. 'Contextualizing Willingness to Participate: Recommendations for Engagement, Recruitment \& Enrolment of Kenyan MSM in Future HIV Prevention Trials'. BMC Public Health 17 (May). https://doi.org/10.1186/s12889-017-4395-4.

Downie, Richard. 2017. 'Advancing Country Partnerships on HIV/AIDS | Center for Strategic and International Studies'. Center for Strategic and International Studies, 9 August 2017. https://www.csis.org/analysis/advancingcountry-partnerships-hivaids.

Editorial Le Monde. 2005. 'La conférence sur le sida en Afrique refuse de faire la promotion de l'abstinence'. Le Monde.fr, 9 December 2005. http://www.lemonde.fr/international/article/2005/12/09/la-conference-sur-lesida-en-afrique-refuse-de-faire-la-promotion-de-l-abstinence_719639_3210.html.

Editorial La Dépêche. n.d. 'Lutte Contre Le VIH/SIDA : En Finir Avec L'abstinence'. Ladepeche.fr. Accessed 11 September 2017. http://www.ladepeche.fr/article/2016/05/11/2342294-lutte-contre-le-vih-sida-en-finir-avecl-abstinence.html.

Firger, Jessica. 2016. '13 Faces of AIDS Activism'. Esquire, 28 November 2016.

http://www.esquire.com/lifestyle/health/g3106/aids-activists/.

Fortin, Jacey. 2017. 'How to Help Hurricane Irma Victims (and How to Avoid Scams)'. The New York Times, 8 September 2017, sec. U.S. https://www.nytimes.com/2017/09/08/us/hurricane-irma-help-donate.html.

Frist, Bill. 2017. 'Opinion | Bill Frist: The Case for Keeping America's AIDS Relief Plan'. The New York Times, 9 February 2017, sec. Opinion. https://www.nytimes.com/2017/02/09/opinion/bill-frist-the-case-for-keepingamericas-aids-relief-plan.html.

Gqola, Pumla Dineo. 2015. Rape: A South African Nightmare.

Hagopian, Amy, Deepa Rao, Aaron Katz, Sallie Sanford, and Scott Barnhart. 2017. 'Anti-Homosexual Legislation and HIV-Related Stigma in African Nations: What Has Been the Role of PEPFAR?' Global Health Action 10 (1). https://doi.org/10.1080/16549716.2017.1306391.

Harris, Gardiner. 2017. 'Cuts to AIDS Treatment Programs Could Cost a Million Lives'. The New York Times, 23 May 2017, sec. Africa. https://www.nytimes.com/2017/05/23/world/africa/cuts-to-aids-treatment-programs-couldcost-a-million-lives.html.

Huni, Shingirai. 2017. 'Let Trump see the speck in his eye first'. The Herald Zimbabwe, 22 September 2017. http://global.factiva.com/redir/default.aspx?P=sa\&an=HRAZI00020170923ed9m00006\&cat=a\&ep=ASE. 
IAS 2017 Plenary Session - 24 July 2017 - YouTube. n.d. Accessed 20 September 2017.

https://www.youtube.com/watch?v=0Ry3idwrm9c.

Jordan, Sara R., and Jaimie Edwards. 2016. 'Defining Agency and Vulnerability: PEPFAR and the Role of Women in HIV/AIDS Prevention'. World Medical \& Health Policy 8 (4):421-43. https://doi.org/10.1002/wmh3.210.

Kim, Youngwan, and Taehee Whang. 2017. 'The Effects of the President's Emergency Plan for AIDS Relief on the Economies and Domestic Politics of Focus Countries'. Global Economic Review 0 (0):1-23.

https://doi.org/10.1080/1226508X.2017.1367316.

Kristiansen, Cathy. 2016. 'PEPFAR's Dr Deborah Birx Urges Sharper Focus to Halt HIV Globally - Fogarty International Center @ NIH'. Fogarty International Center 15 (1).

https://www.fic.nih.gov/news/globalhealthmatters/january-february-2016/pages/deborah-birx-pepfar-globalhiv-control.aspx.

Kristof, Nicholas. 2017. 'Nicholas Kristof: Meet the world leaders - in hypocrisy'. The Scotsman, 23 September 2017. http://global.factiva.com/redir/default.aspx?P=sa\&an=SC00000020170924ed9n0001g\&cat=a\&ep=ASE.

Lavers, Michael K. 2017. 'World AIDS Day Used to Highlight HIV/AIDS Stigma, Discrimination'. Washington Blade: Gay News, Politics, LGBT Rights, 1 December 2017. http://www.washingtonblade.com/2017/12/01/world-aidsday-used-highlight-hivaids-stigma-discrimination/.

Lee, Barbara. 2017. 'Opinion | How to Move Toward an AIDS-Free Generation'. The New York Times, 20 February 2017, sec. Opinion. https://www.nytimes.com/2017/02/20/opinion/how-to-move-toward-an-aids-freegeneration.html.

Leonhardt, David. 2017. 'Opinion | America First, in Africa'. The New York Times, 9 February 2017, sec. Opinion. https://www.nytimes.com/2017/02/09/opinion/america-first-in-africa.html.

Levey, Noam N. 2017. 'Trump Pushes Historic Cuts in Global Health Aid, Stoking Fears of New Disease Outbreaks and Diminished U.S. Clout'. Los Angeles Times, 10 April 2017. http://www.latimes.com/politics/la-na-pol-trumpglobal-health-20170410-story.html.

Mbanje, Phyllis. 2017a. 'Health Ministry Frets over US HIV Funding'. NewsDay Zimbabwe (blog). 16 March 2017. https://www.newsday.co.zw/2017/03/16/health-ministry-frets-us-hiv-funding/.

_- _. 2017b. 'Glimmer of Hope as US Continues HIV Funding'. NewsDay Zimbabwe (blog). 15 May 2017. https://www.newsday.co.zw/2017/05/15/glimmer-hope-us-continues-hiv-funding/.

McGreal, Chris. 2008. 'George Bush: A Good Man in Africa'. The Guardian, 15 February 2008, sec. US news. http://www.theguardian.com/world/2008/feb/15/georgebush.usa.

McKay, Betsy. 2017. 'Health Sector Prepares for Antiabortion Policy's Impact on HIV/AIDS Fight'. Wall Street Journal, 16 May 2017, sec. US. https://www.wsj.com/articles/health-sector-prepares-for-antiabortion-policysimpact-on-hiv-aids-fight-1494908437.

Moucheraud, Corrina, Amee Schwitters, Chantelle Boudreaux, Denise Giles, Peter H. Kilmarx, Ntolo Ntolo, Zwashe Bangani, Michael E St. Louis, and Thomas J Bossert. 2017. 'Sustainability of Health Information Systems: A ThreeCountry Qualitative Study in Southern Africa'. BMC Health Services Research 17 (January). https://doi.org/10.1186/s12913-016-1971-8.

Mugyenyi, Peter. 2013. A Cure Too Far: The Struggle to End HIV/AIDS. Kampala: Fountain.

Nyakudya, Munesu. 2017. 'Usaid Unveils $\$ 20 \mathrm{~m}$ Grant for HIV Treatment'. NewsDay Zimbabwe (blog). 11 August 2017. https://www.newsday.co.zw/2017/08/11/usaid-unveils-20m-grant-hiv-treatment/.

Nyaoke, Borna, Gaudensia N. Mutua, Rose Sajabi, Delvin Nyasani, Marianne W. Mureithi, and Omu A. Anzala. 2017. 'Volunteer Motivators for Participating in HIV Vaccine Clinical Trials in Nairobi, Kenya'. PLOS ONE 12 (September):e0183788. https://doi.org/10.1371/journal.pone.0183788.

O'connor, Siobhan. 2017. 'Brainstorm Health: The Future of HIV Vaccine Development'. Fortune (blog). 3 May 2017. http://fortune.com/video/2017/05/02/brainstorm-health-hiv-cure/.

Okiror, Samuel. 2017. 'End of Joseph Kony Hunt Breeds Frustration and Fear'. IRIN, 26 April 2017. https://www.irinnews.org/analysis/2017/04/26/end-joseph-kony-hunt-breeds-frustration-and-fear.

Onovo, Amobi, Temitayo Odusote, D Nongo, and H Kang. 2017. 'Identification of Geospatial Hotspots of TB/HIV Co-infection Distribution in USAID/PEPFAR'. In . Guadalajara, Mexico.

https://www.researchgate.net/publication/318013986_Title_Identification_of_Geospatial_Hotspots_of_TBHIV_Co -infection_Distribution_in_USAIDPEPFAR_Supported_LGAs_in_Nigeria_Using_GIS_for_Intensified_Case_Findings. 
Onovo, Amobi, Emeka Franklin Okechukwu, U Roxo, and H Kang. 2017. 'Demographic Correlates of Survival in Adult HIV-Infected Patients Initiating First-Line Antiretroviral Therapy in Nigeria: A 7-Year Prospective Cohort Study'. In . Paris, France.

https://www.researchgate.net/publication/318035076_Demographic_Correlates_of_Survival_in_Adult_HIVinfected_Patients_initiating_first-line_Antiretroviral_Therapy_in_Nigeria_a_7-year_Prospective_Cohort_Study.

Opeyemi, Saheed Usman, Adebayo Fatai Kayode, and Usman Ibiwumi Nafisat. 2017. '016.6 Willingness of Young Persons in South-Western Nigeria to Participate in Early Hiv Vaccine Trials'. In Sex Transm Infect, 93:A38.2-A38. https://doi.org/10.1136/sextrans-2017-053264.95.

Osi, Bouaké. n.d. 'Des Associations Condamnent La Politique Américaine “abstinence et Fidélité”'. Accessed 11 September 2017. http://osibouake.org/?Des-associations-condamnent-la.

Provost, Claire. 2012. 'Anti-Prostitution Pledge in US Aids Funding “Damaging” HIV Response'. The Guardian, 24 July 2012, sec. Global development. http://www.theguardian.com/globaldevelopment/2012/jul/24/prostitution-us-aids-funding-sex.

Purvis, Katherine. 2017. 'A Push to End the Global HIV Epidemic'. The Guardian, 9 August 2017, sec. Global Development Professionals Network. http://www.theguardian.com/global-development-professionalsnetwork/2017/aug/09/a-push-to-end-the-global-hiv-epidemic.

Rabesandratana, Tania. 2016. 'Promoting Abstinence to Prevent HIV Doesn't Stop Risky Sex, Study Says'. The Guardian, 27 May 2016, sec. Global development. http://www.theguardian.com/globaldevelopment/2016/may/27/promoting-abstinence-to-prevent-hiv-risky-sex-study.

Rosenberg, Tina. 2017a. 'Opinion | In Africa, a Glimpse of Hope for Beating H.I.V.' The New York Times, 19 September 2017, sec. Opinion. https://www.nytimes.com/2017/09/19/opinion/in-africa-a-glimpse-of-hope-forbeating-hiv.html.

_- _. 2017b. 'Glimpse of hope for a continent'. Daily News, 22 September 2017, E1 edition, sec. LOR.

Rosenthal, Elisabeth. 2008. 'Los Angeles Times Examines Effect of PEPFAR Drug Programs in Africa'. Kaiser Health News (blog). 15 February 2008. http://khn.org/morning-breakout/dr00050439/.

Rushton, Mary. 2015. 'IAVI Report - Six Prominent Women Scientists Making a Difference in the AIDS Fight'. IAVIReport 19 (2).

http://www.iavireport.org/index.php?option=com_content\&view=article\&id=1847\&Itemid=884.

Russell, Asia. 2017. 'Opinion | Trump and AIDS Relief'. The New York Times, 17 April 2017, sec. Opinion. https://www.nytimes.com/2017/04/17/opinion/trump-and-aids-relief.html.

Saldinger, Adva. 2017. 'Amb. Birx on PEPFAR in the Trump Era'. Devex. 14 March 2017. https://www.devex.com/news/sponsored/amb-birx-on-pepfar-in-the-trump-era-89800.

Seib, Philip. 2017. 'A Bush-Obama Alliance Might Save PEPFAR'. Huffington Post (blog). 9 April 2017. http://www.huffingtonpost.com/entry/a-bush-obama-alliance-might-savepepfar_us_58eab766e4b00dd8e016ed4e.

Senthilingam, Meera. n.d. 'HIV Vaccine to Be Trialled in South Africa'. CNN. Accessed 19 September 2017a. http://www.cnn.com/2016/07/19/health/hiv-vaccine-go-ahead-aids-conference/index.html.

_-_ n.d. 'More Evidence Treatment Zeroes HIV Transmission during Sex'. CNN. Accessed 19 September $2017 \mathrm{~b}$. http://www.cnn.com/2017/07/25/health/hiv-zero-transmission-prevention-vaccine-study/index.html.

Shelbourne, Mallory. 2017. 'George W. Bush Pens Op-Ed Urging Full Funding for Anti-AIDS Program'. Text. TheHill. 8 April 2017. http://thehill.com/homenews/news/327949-george-w-bush-urges-lawmakers-tocontinue-funding-pepfar.

Sieff, Kevin. 2016. 'Tanzania Suspends U.S.-Funded AIDS Programs in a New Crackdown on Gays'. Washington Post, 23 November 2016, sec. Africa. https://www.washingtonpost.com/world/africa/tanzania-suspends-usfunded-aids-programs-in-a-new-crackdown-on-gays/2016/11/23/ec6ced6e-ab5c-11e6-8f19-

21a1c65d2043_story.html.

-_- n.d. 'Tanzania Suspends HIV/AIDS Programs in New Crackdown on Gays'. Chicagotribune.com. Accessed 8 September 2017. http://www.chicagotribune.com/news/nationworld/ct-tanzania-crackdown-on-gays20161123-story.html.

Stolberg, Sheryl Gay. 2008. 'In Global Battle on AIDS, Bush Creates Legacy'. The New York Times, 5 January 2008, sec. Washington. https://www.nytimes.com/2008/01/05/washington/05aids.html. 
Tehrani, Marjan, and Gabriel Noble. 2016. Ending AIDS Together - Full Documentary. Tru Films Production. https://www.pepfar.gov/.

Tocco, Jack Ume. 2017. 'The Islamification of Antiretroviral Therapy: Reconciling HIV Treatment and Religion in Northern Nigeria'. Social Science \& Medicine (1982) 190 (August):75-82.

https://doi.org/10.1016/j.socscimed.2017.08.017.

Varmus, Harold. 2013. 'Making PEPFAR'. Science \& Diplomacy, 012013.

http://www.sciencediplomacy.org/article/2013/making-pepfar.

Villarosa, Linda. 2017. 'America's Hidden H.I.V. Epidemic'. The New York Times, 6 June 2017, sec. Magazine. https://www.nytimes.com/2017/06/06/magazine/americas-hidden-hiv-epidemic.html.

Wang, Amy B. 2017. 'Trump "simply Does Not Care" about HIV/AIDS, Say 6 Experts Who Just Quit His Advisory Council'. Washington Post, 19 June 2017, sec. To Your Health. https://www.washingtonpost.com/news/to-yourhealth/wp/2017/06/19/trump-simply-does-not-care-about-hivaids-say-6-experts-who-just-quit-his-advisorycouncil/.

Warren, Rick and Kay. n.d. 'Trump Budget Would Set Back Global AIDS Fight Just When We're on Track to Win It'. USA TODAY. Accessed 6 September 2017. https://www.usatoday.com/story/opinion/2017/07/25/trumpbudget-set-back-global-aids-fight-rick-warren-column/465544001/.

Washington, Reuters. 2017. 'Donald Trump Plans 28\% Cut in Budget for Diplomacy, Foreign Aid'. Text. The Straits Times. 17 March 2017. http://www.straitstimes.com/world/united-states/donald-trump-plans-28-per-cent-cutin-budget-for-diplomacy-foreign-aid.

WHO. 2015. 'Prevention of Mother-to-Child Transmission (PMTCT) of HIV'. AVERT. 20 July 2015. https://www.avert.org/professionals/hiv-programming/prevention/prevention-mother-child. 